\title{
Competition for nitrogen between Pinus sylvestris and ectomycorrhizal fungi generates potential for negative feedback under elevated $\mathrm{CO}_{2}$
}

\author{
Odair Alberton · Thomas W. Kuyper • \\ Antonie Gorissen
}

Received: 12 February 2007/Accepted: 21 May 2007/Published online: 21 June 2007

(C) Springer Science+Business Media B.V. 2007

\begin{abstract}
We investigated fungal species-specific responses of ectomycorrhizal (ECM) Scots pine (Pinus sylvestris) seedlings on growth and nutrient acquisition together with mycelial development under ambient and elevated $\mathrm{CO}_{2}$. Each seedling was associated with one of the following ECM species: Hebeloma cylindrosporum, Laccaria bicolor, Suillus bovinus, S. luteus, Piloderma croceum, Paxillus involutus, Boletus badius, or non-mycorrhizal, under ambient, and elevated $\mathrm{CO}_{2}$ (350 or $700 \mu \mathrm{l}^{-1} \mathrm{CO}_{2}$ ); each treatment contained six replicates. The trial lasted 156 days. During the final 28 days, the seedlings were labeled with ${ }^{14} \mathrm{CO}_{2}$. We measured hyphal length, plant biomass, ${ }^{14} \mathrm{C}$ allocation, and plant nitrogen and phosphorus concentration. Almost all parameters were significantly affected by fungal species and/or $\mathrm{CO}_{2}$. There were very few significant interactions. Elevated $\mathrm{CO}_{2}$ decreased shoot-to-root ratio, most strongly so in species with the largest extraradical mycelium. Under elevated $\mathrm{CO}_{2}, \mathrm{ECM}$ root growth increased significantly more than hyphal
\end{abstract}

Responsible Editor: Herbert Johannes Kronzucker

O. Alberton $(\bowtie) \cdot$ T. W. Kuyper

Department of Soil Quality, Wageningen University, PO Box 47, 6700 AA Wageningen, The Netherlands e-mail: odair.alberton@wur.nl; oalberton@yahoo.com.br

\section{A. Gorissen}

IsoLife, PO Box 349, 6700 AH Wageningen,

The Netherlands growth. Extraradical hyphal length was significantly negatively correlated with shoot biomass, shoot $\mathrm{N}$ content, and total plant $\mathrm{N}$ uptake. Root dry weight was significantly negatively correlated with root $\mathrm{N}$ and $\mathrm{P}$ concentration. Fungal sink strength for $\mathrm{N}$ strongly affected plant growth through $\mathrm{N}$ immobilization. Mycorrhizal fungal-induced progressive nitrogen limitation (PNL) has the potential to generate negative feedback with plant growth under elevated $\mathrm{CO}_{2}$.

Keywords Carbon and nitrogen allocation . Ectomycorrhizal fungi - Elevated $\mathrm{CO}_{2} \cdot$ Extraradical hyphae $\cdot$ Mycocentric $\cdot \mathrm{N}$ immobilization ·

Progressive nitrogen limitation $\cdot$ Pinus sylvestris

\section{Introduction}

Responses to elevated $\mathrm{CO}_{2}$ have often been studied from the plant's perspective (phytocentric approach) and less often from the fungal perspective (mycocentric approach) in which carbon and nutrient sink strength of the fungus plays an important role (Fitter et al. 2000; Staddon 2005). It has often been assumed that plant and fungal responses are coordinated and of the same magnitude, implying that elevated $\mathrm{CO}_{2}$ provides roughly similar benefits for both symbiotic partners (Alberton et al. 2005; Reich et al. 2006) Under such conditions positive feedbacks between increased carbon availability and increased nutrient availability are likely to occur, leading to sustained 
increased productivity of the plant. However, Diaz et al. (1993) hypothesized that an enhanced C flow to the soil increases nutrient immobilization by (saprotrophic) microbiota and hence decreases plant nutrient availability, which provides a negative feedback and limits plant response to elevated $\mathrm{CO}_{2}$. Such microbially induced progressive nitrogen limitation (PNL) potentially decreases plant response to rising atmospheric $\mathrm{CO}_{2}$ (Luo et al. 2004; Hu et al. 2006). Furthermore, a recent meta-analysis of mycorrhizal plant and fungal responses to elevated $\mathrm{CO}_{2}$ suggested that in ectomycorrhizal (ECM) symbioses, fungal responses are larger than plant responses (Alberton et al. 2005). On average, doubling atmospheric $\mathrm{CO}_{2}$ concentration led to an increase of $45 \%$ of the ECM mycelium and $26 \%$ of the plant. As a consequence of this differential response, competition between mycorrhizal plant and fungus for nutrients could increase.

The meta-analysis also indicated that different fungal species derive similar benefits from elevated $\mathrm{CO}_{2}$, but that fungal species identity matters very much from the plant's perspective. Plants associated with individual fungal species also showed a significantly lower response to elevated $\mathrm{CO}_{2}$ than plants that were colonized by a fungal assemblage. Alberton et al. (2005) proposed two hypotheses to explain this observation. Elevated $\mathrm{CO}_{2}$ could result in a shift in the fungal assemblage toward species that have lower nutrient-to-carbon demands (Fransson et al. 2001; Parrent et al. 2006). The alternative hypothesis is that research results are biased by selection of species that perform well under the conditions normally encountered in experiments, but that are not sufficiently representative for fungal assemblages in the field. Research bias likely leads to overrepresentation of ECM fungi that tend to be nutrient-limited rather than carbon-limited, since ECM fungi contain higher concentration of $\mathrm{N}$ than plant material (Colpaert et al. 1996). Because the meta-analysis indicated that fungal species identity was a major determinant of the outcome of individual studies, Alberton et al. (2005) also suggested argued choices in species selection for experiments. Because only a limited number of species have been investigated to date, there is a clear need for testing ECM plant and fungal responses to elevated $\mathrm{CO}_{2}$ by a number of different fungal species, with different carbon and nutrient economies, in one experiment (see also Fransson et al. 2007).
This work aimed at investigating fungal speciesspecific responses of ECM Scots pine seedlings under controlled conditions at ambient and elevated $\mathrm{CO}_{2}$. We hypothesized that (1) elevated $\mathrm{CO}_{2}$ will increase carbon allocation to the fungus; (2) enhanced allocation will increase nutrient immobilization in fungal tissue; (3) larger nutrient immobilization in fungal tissue will show negative feedback to plant nutrient content and ultimately plant biomass due PNL; (4) under such conditions mycorrhizal associations may constrain plant responses to elevated $\mathrm{CO}_{2}$; (5) these effects will be strongest in species that produce the largest amount of mycelium. In other words, this study sought for evidence of nutrient competition and hence PNL between ECM fungus and plant in order to improve our understanding and predictive ability of ECM functioning under elevated $\mathrm{CO}_{2}$.

\section{Materials and methods}

Plants, fungi, and substrate

Seeds of Scots pine (Pinus sylvestris), purchased from PVM, Grubbenvorst, The Netherlands, were soaked in demineralized water overnight, and then surface-sterilized in a $30 \% \mathrm{H}_{2} \mathrm{O}_{2}$-solution containing a drop of Tween 20 during $30 \mathrm{~min}$. The sterilized seeds were germinated on sterile water agar media containing $5 \mathrm{~g} \mathrm{l}^{-1}$ of glucose. After 3 weeks, each seedling was transferred to a Petri dish $(\varnothing 14.5 \mathrm{~cm})$, filled with $50 \mathrm{~g}$ of a sterilized $\left(1 \mathrm{~h}\right.$ at $\left.110^{\circ} \mathrm{C}\right)$ peatvermiculite mixture $(2: 5, \mathrm{w} / \mathrm{w})$. The mixture contained $29.9 \mathrm{mg} \mathrm{kg}^{-1}$ of available mineral $\mathrm{N}$ and $1.4 \mathrm{mg} \mathrm{kg}^{-1}$ of available P. The peat-vermiculite mixture was moistened with $50 \mathrm{ml}$ full-strength modified Melin-Norkrans (MMN) solution (without agar, glucose, and malt extract) at the start of the experiment. MMN solution was used to ensure that both mycorrhizal and non-mycorrhizal treatments were solely limited by $\mathrm{N}$ (and not by $\mathrm{P}$ ), and to prevent a decrease in $\mathrm{pH}$ due the ammonium-N uptake during the experiment (Kamminga-van Wijk and Prins 1989). During the experiment we furthermore added five times $23 \mathrm{ml} \mathrm{MMN}$. In total, $8.66 \mathrm{mg}$ of $\mathrm{N}$ and $28.48 \mathrm{mg}$ of $\mathrm{P}$ were added to each Petri dish. Each seedling was inoculated around the root system with 12 plugs of actively growing mycelium of one of 
the following ECM species: Hebeloma cylindrosporum (CBS 558.96, kindly provided by Centraalbureau voor Schimmelcultures CBS, Utrecht, The Netherlands), Laccaria bicolor, Suillus bovinus, S. luteus, Piloderma croceum (BL 97-01, kindly provided by R. Finlay, SLU, Uppsala, Sweden), Paxillus involutus, Boletus badius. A non-mycorrhizal treatment was also included. The isolates of L. bicolor, S. bovinus, S. luteus, P. involutus, and B. badius were isolated from fruitbodies collected in the surroundings of Harderwijk, The Netherlands, in 2004. The Petri dishes were hermetically sealed with parafilm and tape, covered with aluminum foil, but contained three openings. The median opening allowed shoots to grow out of the dish using lanoline for sealing, while one lateral opening could be instantaneously opened for water addition, after which it was closed again. During the labeling, the third opening was connected to a PVC tube $(\varnothing 2 \mathrm{~cm}$; length $15 \mathrm{~cm})$ containing three layers of soda-lime (carbosorb) separated by cotton plugs to trap root and mycorrhizal respiration and to permit the free exchange of oxygen. Approximately $7.5 \mathrm{~g}$ of soda-lime were used in the lower layer to capture respiration. The upper layer served as a barrier to capture $\mathrm{CO}_{2}$ entering from atmosphere, and the layer in between was used as a background.

Plant growth and experimental conditions

The seedlings were placed into four growth chambers (two for each $\mathrm{CO}_{2}$ level) with a steady flow of either 350 or $700 \mu \mathrm{l} \mathrm{l}^{-1} \mathrm{CO}_{2}$. Temperatures were maintained at $20^{\circ} \mathrm{C}$ during the day $(16 \mathrm{~h}$, irradiation $250 \mu \mathrm{mol} \mathrm{m} \mathrm{m}^{-2} \mathrm{~s}^{-1}$ ) and at $16^{\circ} \mathrm{C}$ during the night $(8 \mathrm{~h})$, and relative humidity was kept around $70 \%$. The Petri dishes were randomized every 2 weeks within each growth chamber. After 128 days, the Petri dishes were transferred to the Experimental Soil Plant Atmosphere System (ESPAS; Gorissen et al. 1996). The seedlings were exposed to ${ }^{14} \mathrm{CO}_{2}$

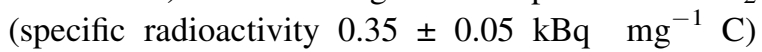
supplied from a pressurized cylinder for an additional 28 days. The growth conditions (temperature, relative humidity, and $\mathrm{CO}_{2}$ level) in the ESPAS were equal to the growth chambers, except for the photosynthetically active irradiation level, which was increased to $360 \mu \mathrm{mol} \mathrm{m} \mathrm{m}^{-2} \mathrm{~s}^{-1}$ for the first 2 weeks and $460 \mu \mathrm{mol} \mathrm{m} \mathrm{m}^{-2} \mathrm{~s}^{-1}$ for the last 2 weeks.
Analyses

All seedlings were harvested 28 days after ${ }^{14} \mathrm{C}$ labeling started. Plants were removed from Petri dishes; shoots, roots, and the peat-vermiculite mixture were separated and dried at $70^{\circ} \mathrm{C}$ for $48 \mathrm{~h}$. These fractions were subsequently ground and analyzed for total ${ }^{14} \mathrm{C}$ content with a modified wet combustion method (Dalal 1979). Plant material (30 mg) and peat-vermiculite $(0.5 \mathrm{~g})$ were digested in duplicate in $5 \mathrm{ml}$ of a $10 \%(\mathrm{w} / \mathrm{v})$ solution of $\mathrm{K}_{2} \mathrm{Cr}_{2} \mathrm{O}_{7}$ in a mixture of concentrated $\mathrm{H}_{2} \mathrm{SO}_{4}$ and $\mathrm{H}_{3} \mathrm{PO}_{4}(3: 2, \mathrm{v} / \mathrm{v})$ at $160^{\circ} \mathrm{C}$ for $2 \mathrm{~h}$. The ${ }^{14} \mathrm{CO}_{2}$ evolved was trapped in $10 \mathrm{ml}$ of $0.5 \mathrm{M} \mathrm{NaOH}$. The ${ }^{14} \mathrm{C}$ was determined in $0.5 \mathrm{ml}$ of $\mathrm{NaOH}$ by liquid scintillation counting (Tri-Carb 2100TR; Packard Instrument Company, Meriden, CT, USA) with $3 \mathrm{ml}$ of Ultima Gold (Packard).

The soda-lime containing the respired ${ }^{14} \mathrm{CO}_{2}$ was transferred to bottles $(0.5 \mathrm{l})$ and dissolved in $50 \mathrm{ml}$ excess $6 \mathrm{M} \mathrm{HCl}$, injected through a septum in the lid. The ${ }^{14} \mathrm{CO}_{2}$ evolved was captured in $10 \mathrm{ml}$ of $5 \mathrm{M}$ $\mathrm{NaOH}$ and analyzed by liquid scintillation counting as described.

$\mathrm{N}$ and $\mathrm{P}$ concentrations in shoots and roots were determined colorimetrically by automated flow analysis after digestion of samples with $\mathrm{H}_{2} \mathrm{SO}_{4}$-salicyclic acid $-\mathrm{H}_{2} \mathrm{O}_{2}$ and selenium (Temminghoff and Houba 2004).

The total extraradical hyphal length in the peatvermiculite mixture was determined with the gridline intersection method and fluorescent staining as outlined by Bloem and Vos (2004). We did not subtract hyphal length as measured in the control treatments from hyphal length as measured in the mycorrhizal treatments.

\section{Statistical analyses}

The experiment consisted of two $\mathrm{CO}_{2}$ concentrations (350 or $700 \mu \mathrm{ll}^{-1} \mathrm{CO}_{2}$ ), eight mycorrhizal treatments (seven ECM species and a non-mycorrhizal control) and six replicates for each treatment. A total of 96 seedlings were included $(2 \times 8 \times 6)$. In the growth chamber, all Petri dishes for treatment combinations were completely randomized. In order to comply with ANOVA assumptions for homogeneity (Levene's test), the following variables were $\log _{10}$ transformed before analysis: extraradical hyphal length, root dry weight, shoot-to-root dry weight ratio, ${ }^{14} \mathrm{C}$ in shoots, 
${ }^{14} \mathrm{C}$ in shoot-to-root ratio, net ${ }^{14} \mathrm{C}$ uptake per unit shoot mass, $\mathrm{N}$ concentration in shoots and roots, $\mathrm{P}$ concentration in roots, $\mathrm{N}$ content in shoots, $\mathrm{P}$ content in roots, and $\mathrm{N}$ uptake efficiency. ANOVA followed by Tukey's honestly significant difference (HSD) post hoc test was performed using SPSS Version 12.0.1 for Windows (SPSS Inc., Chicago, IL, USA). Considering the large number of parameters measured and calculated (26), a sequential Bonferroni correction was applied to keep the $P$-value constant at $P<0.05$. Pearson pairwise correlation coefficients were calculated and their significance determined in two-tailed $t$-test as indicators of direction of relationship between plant and fungal parameters.

\section{Results}

No differences were observed between the results from both growth chambers for each $\mathrm{CO}_{2}$ level, and they were therefore combined. The respiration measurements showed very low and variable values $\left({ }^{14} \mathrm{C}\right.$ trapped in respiration usually between 0.5 and $1 \%$ of ${ }^{14} \mathrm{C}$ in roots). We concluded that the carbosorb traps were most likely leaky, because respiration data are normally an order of magnitude larger (Gorissen et al. 1991; Andersen and Rygiewicz 1995). Therefore, no data on below-ground respiration and below-ground carbon use efficiency (Gorissen and Kuyper 2000) are reported.

Almost all parameters were significantly affected by $\mathrm{CO}_{2}$ and/or fungal species. There were very few significant interactions (Table 1). The non-mycorrhizal plants performed equally well or significantly better than some mycorrhizal treatments. Omission of the non-mycorrhizal control did in general not affect the significance of the various parameters (data not shown). The parameters will be discussed in the following order: hyphal length, root, and shoot.

Hyphal length was significantly affected by fungal species, but not by elevated $\mathrm{CO}_{2}$. Hyphal length increased by $12 \%$ under elevated $\mathrm{CO}_{2}$, but the increment was not significant (Table 1). Average hyphal length (for both $\mathrm{CO}_{2}$ levels) ranged from 54 (S. bovinus) to 634 (H. cylindrosporum) $\mathrm{m} \mathrm{g}^{-1}$ substrate (Table 2). Hyphal length in the nonmycorrhizal treatment was on average $29 \mathrm{~m} \mathrm{~g}^{-1}$ substrate. Incorporation of ${ }^{14} \mathrm{C}$ in the substrate (where are roots and external mycelia) followed a fairly similar pattern but showed more variability (higher coefficient of variation). It was lowest in the nonmycorrhizal control and in the treatment with $S$. bovinus, and highest in the treatments with H. cylindrosporum, L. bicolor, and P. croceum (elevated $\mathrm{CO}_{2}$ only) (Table 3 ).

Root dry weight was significantly affected by $\mathrm{CO}_{2}$ level and fungal species, and not by the interaction (Table 1). Under elevated $\mathrm{CO}_{2}$ root dry weight increased on average by $52 \%$. Root biomass was highest in the treatment with $P$. croceum and lowest in the treatments with $H$. cylindrosporum and $L$. bicolor (Fig. 1). ${ }^{14} \mathrm{C}$ incorporation in roots was also significantly affected by $\mathrm{CO}_{2}$ level and fungal species, and not by the interaction. Elevated $\mathrm{CO}_{2}$ increased ${ }^{14} \mathrm{C}$ activity in roots by $87 \%$. Plants inoculated with $H$. cylindrosporum and L. bicolor presented the lowest ${ }^{14} \mathrm{C}$ activity (Table 3 ). Root dry weight and ${ }^{14} \mathrm{C}$ incorporation in roots were significantly positively correlated $(r=0.73, P<0.01)$. Root $\mathrm{N}$ and $\mathrm{P}$ concentration were also significantly affected by $\mathrm{CO}_{2}$ level and fungal species, and not by the interaction. Elevated $\mathrm{CO}_{2}$ decreased root $\mathrm{N}$ concentration on average by $14 \%$ and root $\mathrm{P}$ concentration on average by $7 \%$. Root $\mathrm{N}$ concentrations varied between 6 and $9 \mathrm{mg} \mathrm{g}^{-1}$, and were lowest in the treatment with $P$. croceum and highest in the treatment with $H$. cylindrosporum (Table 4). Because elevated $\mathrm{CO}_{2}$ increased root dry weight $(52 \%)$, the total amount of $\mathrm{N}$ and $\mathrm{P}$ in roots increased under elevated $\mathrm{CO}_{2}$ by 32 and $41 \%$, respectively. Again, both $\mathrm{CO}_{2}$ level and fungal species, but not the interaction, were significant. Root $\mathrm{N}$ content was highest in the treatment with $P$. croceum and lowest in the treatments with $H$. cylindrosporum and $L$. bicolor (Table 4). Root dry weight was significantly negatively correlated with shoot: root ratio $(r=-0.81 ; P<0.001)$ and root $\mathrm{N}$ concentration ( $r=-0.91 ; P<0.001$ ) (Fig. 2). $\mathrm{N}$ uptake efficiency (mg N content $\mathrm{g}^{-1}$ non-mycorrhizal root dry weight or ectomycorrhiza) was significantly affected by $\mathrm{CO}_{2}$ level and fungal species (Table 1). It ranged between 12 and 16 for ambient $\mathrm{CO}_{2}$, and 8 and 11 for elevated $\mathrm{CO}_{2}$ (Table 4). $\mathrm{N}$ uptake efficiency was lower for $P$. croceum than for the other mycorrhizal fungi and non-mycorrhizal treatment.

Shoot dry weight was significantly affected by fungus but not by elevated $\mathrm{CO}_{2}$ (Table 1). On average shoot dry weight increased under elevated 
Table $1 P$-values from a two-way ANOVA for fungal and plant responses to $\mathrm{CO}_{2}$ treatments with different fungal species inoculated

\begin{tabular}{|c|c|c|c|}
\hline Parameters & $\mathrm{CO}_{2}$ & Fungus & $\mathrm{CO}_{2} \times$ fungus \\
\hline Hyphal length ( $\mathrm{m} \mathrm{g}^{-1}$ substrate) & 0.106 & $0.000 * *$ & 0.017 \\
\hline Root dry weight (g) & $0.000 * *$ & $0.000 * *$ & 0.017 \\
\hline Shoot dry weight (g) & 0.186 & $\mathbf{0 . 0 0 0} * *$ & 0.099 \\
\hline Total dry weight (g) & $\mathbf{0 . 0 0 0} * *$ & $0.000 * *$ & 0.009 \\
\hline Shoot-to-root dry weight ratio & $\mathbf{0 . 0 0 0} * *$ & $0.000 * *$ & 0.300 \\
\hline${ }^{14} \mathrm{C}$ in roots $(\mathrm{kBq})$ & $0.000 * *$ & $\mathbf{0 . 0 0 1} * *$ & 0.314 \\
\hline${ }^{14} \mathrm{C}$ in substrate $(\mathrm{kBq})$ & 0.029 & $\mathbf{0 . 0 0 0} * *$ & $0.002 *$ \\
\hline${ }^{14} \mathrm{C}$ in shoots $(\mathrm{kBq})$ & 0.940 & $0.000 * *$ & 0.029 \\
\hline${ }^{14} \mathrm{C}$ uptake by shoots (mg) & $0.000 * *$ & $0.000 * *$ & 0.029 \\
\hline${ }^{14} \mathrm{C}$ in shoot-to-root ratio & $0.000 * *$ & 0.066 & 0.089 \\
\hline Net ${ }^{14} \mathrm{C}$ uptake $(\mathrm{kBq})$ & $0.000 * *$ & $0.000 * *$ & 0.042 \\
\hline Net ${ }^{14} \mathrm{C}$ uptake per unit shoot mass $\left(\mathrm{kBq} \mathrm{mg}^{-1}\right)$ & $0.000 * *$ & $0.006 *$ & 0.175 \\
\hline $\mathrm{N}$ concentration in roots $\left(\mathrm{mg} \mathrm{g}^{-1}\right)$ & $\mathbf{0 . 0 0 0} * *$ & $0.000 * *$ & 0.461 \\
\hline $\mathrm{N}$ content in roots $(\mathrm{mg})$ & $\mathbf{0 . 0 0 0} * *$ & $\mathbf{0 . 0 0 0} * *$ & 0.019 \\
\hline $\mathrm{N}$ concentration in shoots $\left(\mathrm{mg} \mathrm{g}^{-1}\right)$ & $\mathbf{0 . 0 0 0} * *$ & $0.000 * *$ & 0.018 \\
\hline $\mathrm{N}$ content in shoots $(\mathrm{mg})$ & $\mathbf{0 . 0 0 0} * *$ & $\mathbf{0 . 0 0 0} * *$ & $0.001 *$ \\
\hline Total N uptake (mg) & 0.047 & $\mathbf{0 . 0 0 0} * *$ & $0.002 *$ \\
\hline $\mathrm{N}$ uptake efficiency (mg $\mathrm{N} \mathrm{g}^{-1}$ root) & $\mathbf{0 . 0 0 0} * *$ & $\mathbf{0 . 0 0 0} * *$ & 0.188 \\
\hline $\mathrm{P}$ concentration in roots $\left(\mathrm{mg} \mathrm{g}^{-1}\right)$ & $\mathbf{0 . 0 0 4} *$ & $0.000 * *$ & 0.202 \\
\hline $\mathrm{P}$ content in roots $(\mathrm{mg})$ & $\mathbf{0 . 0 0 0} * *$ & $0.000 * *$ & 0.115 \\
\hline $\mathrm{P}$ concentration in shoots $\left(\mathrm{mg} \mathrm{g}^{-1}\right)$ & $0.001 * *$ & $0.000 * *$ & 0.545 \\
\hline $\mathrm{P}$ content in shoots $(\mathrm{mg})$ & 0.011 & 0.065 & 0.018 \\
\hline Total P uptake (mg) & $\mathbf{0 . 0 0 0} * *$ & $\mathbf{0 . 0 0 0} * *$ & 0.045 \\
\hline $\mathrm{N}$-to-P concentration ratio in roots & $0.002 *$ & 0.089 & 0.164 \\
\hline $\mathrm{N}$-to-P concentration ratio in shoots & $0.000 * *$ & $\mathbf{0 . 0 0 0} * *$ & 0.107 \\
\hline Total N-to-P uptake ratio & $0.000 * *$ & 0.161 & 0.131 \\
\hline
\end{tabular}

$* P \leq 0.01 ; * * P \leq 0.001$; Differences in bold are still significant after the sequential Bonferroni correlation to avoid type-I errors

$\mathrm{CO}_{2}$ by $6 \%$. Shoot dry weight was lowest in the treatment with $H$. cylindrosporum (Table 2). ${ }^{14} \mathrm{C}$ incorporation in shoots followed the same pattern (it increased under elevated $\mathrm{CO}_{2}$ by only $3 \%$ ), and both parameters were significantly correlated $(r=0.83$; $P<0.001)$. The activity of ${ }^{14} \mathrm{C}$ in shoots in $H$. cylindrosporum-colonized plants was lowest, whereas the activity of ${ }^{14} \mathrm{C}$ in shoots in $S$. bovinus-colonized plants was highest (Table 3 ). Shoot dry weight was significantly negatively correlated with hyphal length $(r=-0.70 ; P<0.01 ; \log$ scale to improve the homogeneity of variances; Fig. 3a).

Shoot $\mathrm{N}$ concentration ranged between 8 and $12 \mathrm{mg} \mathrm{g}^{-1}$ under ambient $\mathrm{CO}_{2}$ and 6-7 $\mathrm{mg} \mathrm{g}^{-1}$ under elevated $\mathrm{CO}_{2}$ (Table 4). Under elevated $\mathrm{CO}_{2}$ shoot $\mathrm{N}$ concentrations decreased on average by $29 \%$. Shoot $\mathrm{N}$ concentrations were highest in plants inoculated with $P$. croceum, and lowest in non-mycorrhizal plants and plants inoculated with $H$. cylindrosporum and L. bicolor. P concentration in the shoots was highest in plants colonized by $H$. cylindrosporum and lowest in non-mycorrhizal plants and plants colonized by $L$. bicolor and P. involutus. Because shoot dry weight increased under elevated $\mathrm{CO}_{2}$ and $\mathrm{N}$ concentration decreased, shoot $\mathrm{N}$ content decreased by $24 \%$. Shoot $N$ was lowest in plants inoculated with H. cylindrosporum. Shoot $\mathrm{N}$ content was significantly negatively correlated with hyphal length $(r=-0.57$; $P<0.02$ ) (Fig. 3b). 
Table 2 Extraradical hyphal length ( $\mathrm{m} \mathrm{g}^{-1}$ substrate) and seedling biomass $(\mathrm{g})$ responses to fungal species and $\mathrm{CO}_{2}$ treatments

\begin{tabular}{lllllll}
\hline Fungal species & $\mathrm{CO}_{2}\left(\mu \mathrm{l}^{-1}\right)$ & Hyphal length & Root dry weight & Shoot dry weight & Total dry weight & Shoot-to-root ratio \\
\hline H. cylindrosporum & 350 & $600 \pm 270 \mathrm{a}$ & $0.37 \pm 0.08 \mathrm{~g}$ & $0.23 \pm 0.07 \mathrm{c}$ & $0.60 \pm 0.15 \mathrm{f}$ & $0.61 \pm 0.1 \mathrm{abc}$ \\
& 700 & $669 \pm 468 \mathrm{a}$ & $0.67 \pm 0.14 \mathrm{bcdef}$ & $0.26 \pm 0.06 \mathrm{bc}$ & $0.93 \pm 0.19 \mathrm{cdef}$ & $0.38 \pm 0.05 \mathrm{~cd}$ \\
L. bicolor & 350 & $224 \pm 54 \mathrm{ab}$ & $0.43 \pm 0.05 \mathrm{fg}$ & $0.41 \pm 0.05 \mathrm{a}$ & $0.84 \pm 0.05 \mathrm{def}$ & $0.97 \pm 0.19 \mathrm{a}$ \\
& 700 & $248 \pm 63 \mathrm{ab}$ & $0.70 \pm 0.09 \mathrm{abcde}$ & $0.34 \pm 0.06 \mathrm{abc}$ & $1.04 \pm 0.13 \mathrm{bcde}$ & $0.49 \pm 0.06 \mathrm{bcd}$ \\
S. bovinus & 350 & $73 \pm 31 \mathrm{cdef}$ & $0.47 \pm 0.16 \mathrm{efg}$ & $0.30 \pm 0.08 \mathrm{abc}$ & $0.78 \pm 0.23 \mathrm{ef}$ & $0.68 \pm 0.2 \mathrm{ab}$ \\
& 700 & $35 \pm 9 \mathrm{fg}$ & $1.03 \pm 0.07 \mathrm{ab}$ & $0.44 \pm 0.03 \mathrm{a}$ & $1.46 \pm 0.07 \mathrm{a}$ & $0.43 \pm 0.05 \mathrm{bcd}$ \\
S. luteus & 350 & $116 \pm 51 \mathrm{bcde}$ & $0.47 \pm 0.06 \mathrm{defg}$ & $0.32 \pm 0.04 \mathrm{abc}$ & $0.78 \pm 0.07 \mathrm{ef}$ & $0.68 \pm 0.12 \mathrm{ab}$ \\
& 700 & $111 \pm 14 \mathrm{bcd}$ & $0.72 \pm 0.21 \mathrm{abcd}$ & $0.35 \pm 0.07 \mathrm{abc}$ & $1.08 \pm 0.23 \mathrm{bcde}$ & $0.53 \pm 0.22 \mathrm{bcd}$ \\
$P$. croceum & 350 & $143 \pm 59 \mathrm{bcd}$ & $0.85 \pm 0.14 \mathrm{abc}$ & $0.33 \pm 0.04 \mathrm{abc}$ & $1.18 \pm 0.1 \mathrm{abcd}$ & $0.41 \pm 0.14 \mathrm{~cd}$ \\
& 700 & $180 \pm 64 \mathrm{bc}$ & $1.09 \pm 0.2 \mathrm{a}$ & $0.35 \pm 0.07 \mathrm{abc}$ & $1.45 \pm 0.24 \mathrm{a}$ & $0.33 \pm 0.07 \mathrm{~d}$ \\
$P$. involutus & 350 & $54 \pm 24 \mathrm{def}$ & $0.64 \pm 0.17 \mathrm{cdef}$ & $0.41 \pm 0.08 \mathrm{a}$ & $1.05 \pm 0.2 \mathrm{bcde}$ & $0.69 \pm 0.22 \mathrm{ab}$ \\
& 700 & $70 \pm 23 \mathrm{cdef}$ & $0.76 \pm 0.15 \mathrm{abc}$ & $0.39 \pm 0.1 \mathrm{ab}$ & $1.15 \pm 0.22 \mathrm{abcd}$ & $0.53 \pm 0.11 \mathrm{bcd}$ \\
B. badius & 350 & $88 \pm 57 \mathrm{cdef}$ & $0.65 \pm 0.23 \mathrm{cdef}$ & $0.38 \pm 0.06 \mathrm{abc}$ & $1.03 \pm 0.21 \mathrm{bcde}$ & $0.65 \pm 0.28 \mathrm{abc}$ \\
& 700 & $119 \pm 55 \mathrm{bcde}$ & $0.84 \pm 0.09 \mathrm{abc}$ & $0.39 \pm 0.09 \mathrm{ab}$ & $1.22 \pm 0.16 \mathrm{abc}$ & $0.47 \pm 0.1 \mathrm{bcd}$ \\
Non-mycorrhizal & 350 & $17 \pm 8 \mathrm{~g}$ & $0.59 \pm 0.05 \mathrm{cdef}$ & $0.39 \pm 0.05 \mathrm{ab}$ & $0.98 \pm 0.08 \mathrm{bcde}$ & $0.65 \pm 0.08 \mathrm{ab}$ \\
& 700 & $40 \pm 18 \mathrm{ef}$ & $0.92 \pm 0.13 \mathrm{abc}$ & $0.41 \pm 0.15 \mathrm{ab}$ & $1.33 \pm 0.26 \mathrm{ab}$ & $0.44 \pm 0.1 \mathrm{bcd}$ \\
\hline
\end{tabular}

Mean values \pm SD are shown. Means within a column followed by different letters are significantly different

Total plant dry biomass increased by $33 \%$ under elevated $\mathrm{CO}_{2}$ and once again presented significant differences due to fungal species. Total plant biomass was lowest in the treatment with $H$. cylindrosporum and highest in the treatment with $P$. croceum (Table 2). Elevated $\mathrm{CO}_{2}$ resulted in an average increase of ${ }^{14} \mathrm{C}$ incorporation by $46 \%$, with significant differences between species (Table 1). On average, total $\mathrm{N}$ uptake increased by $8 \%$ under elevated $\mathrm{CO}_{2}$. It was affected by fungal species and by the interaction fungal species $\times \mathrm{CO}_{2}$, but not by $\mathrm{CO}_{2}$ (Table 1). Plants colonized by $H$. cylindrosporum, L. bicolor, and S. luteus showed the lowest total $\mathrm{N}$ uptake and plants colonized by $P$. croceum and $B$. badius the highest (Table 4 ). Total $\mathrm{N}$ uptake was also significantly negatively correlated with hyphal length $(r=-0.54 ; P<0.05)$ (Fig. 3c). Under elevated $\mathrm{CO}_{2} \mathrm{P}$ uptake increased by $32 \%$. Total $\mathrm{P}$ uptake was also affected by fungal species, but not by the interaction. Total P uptake was lower in plants colonized by H. cylindrosporum, L. bicolor, and S. luteus than in plants colonized by P. croceum (Table 5).

Shoot: root ratio was significantly affected by elevated $\mathrm{CO}_{2}$ and fungal species and not by their interaction. On average, elevated $\mathrm{CO}_{2}$ reduced shoot: root ratio from 0.67 to 0.45 , a decrease of $33 \%$. Shoot: root ratio was lowest in plants inoculated with
P. croceum. Shoot: root ratio and the ratio of ${ }^{14} \mathrm{C}$ incorporation in shoots and roots were significantly correlated $(r=0.75 ; P<0.001)$. The ${ }^{14} \mathrm{C}$ in shoot: root ratio decreased by $52 \%$ under elevated $\mathrm{CO}_{2}$. This decrease, caused by an increased $\mathrm{C}$ allocation to the roots compared to the shoots during the final 4 weeks of the experiment, indicated increased sink strength below-ground.

\section{Discussion}

In our experiment hyphal length of seven different ECM fungal species did not significantly increase under elevated $\mathrm{CO}_{2}$. The average increase of $12 \%$ was much lower than the value of $34 \%$ of the general ECM fungal response (i.e., mycelial dry weight, mycelial area, hyphal length, etc.) reported by Alberton et al. (2005). Our experiment did therefore not provide complete support for our first hypothesis. Plant performance (with regard to $\mathrm{N}$ ) suggests an explanation for the lack of a fungal response.

Mycorrhizal symbiosis often enhances plant growth due to increased nutrient uptake compared to non-mycorrhizal plants. However, in our experiment the non-mycorrhizal plants performed equally well or significantly better than in some mycorrhizal 


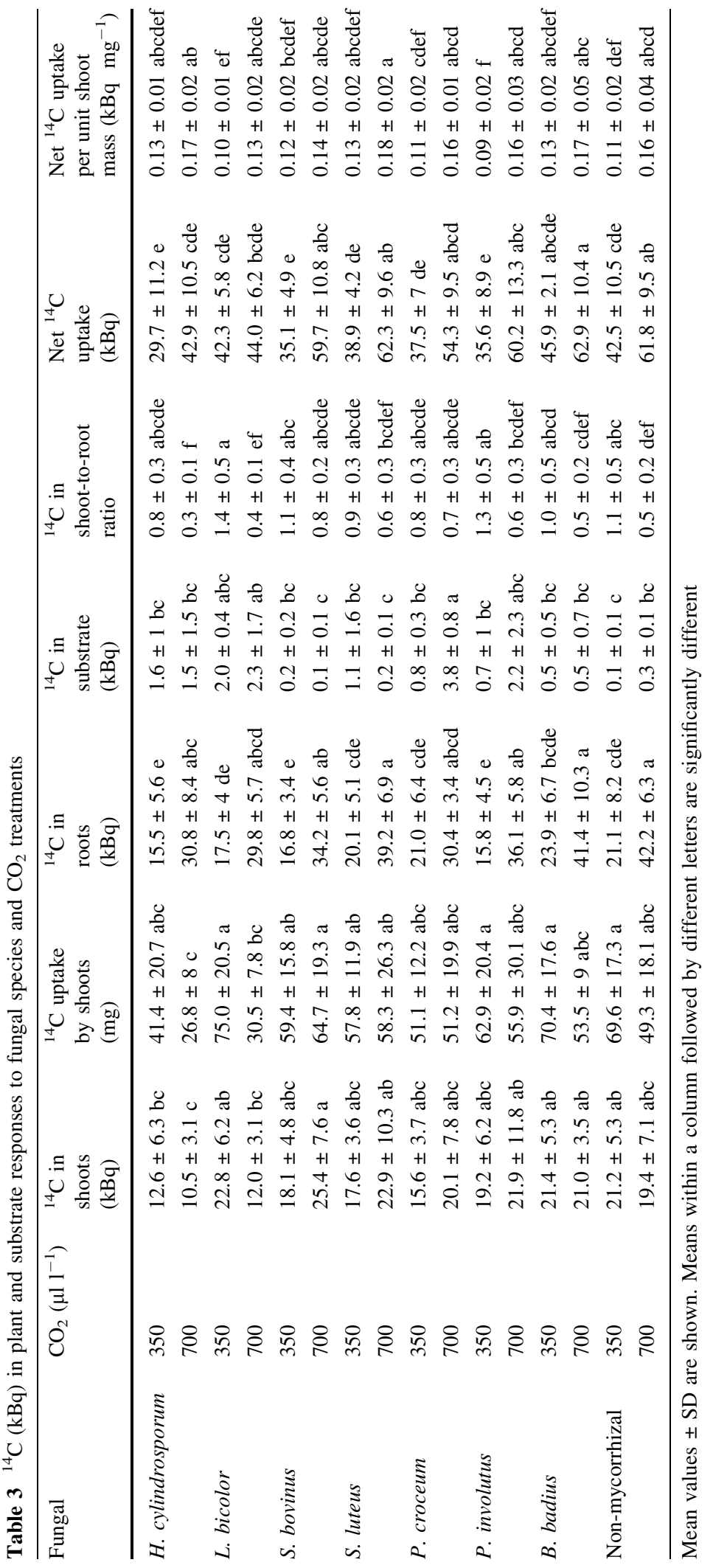




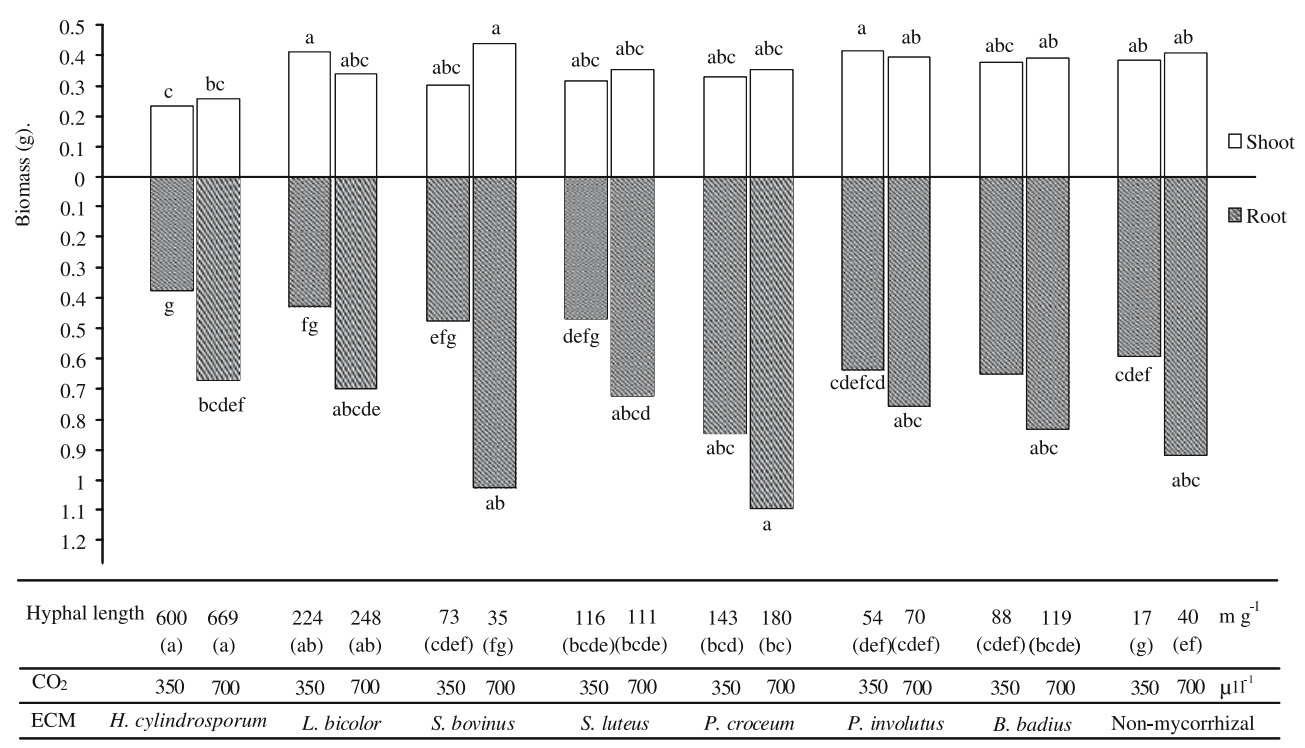

Fig. 1 Main effect of 7 ECM species and non-mycorrhizal treatment under 350 or $700 \mu 1^{-1} \mathrm{CO}_{2}$ on plant shoot and root biomass $(\mathrm{g})$, and extraradical hyphal length $\left(\mathrm{m} \mathrm{g}^{-1}\right.$ substrate)

treatments. Especially plants colonized by $H$. cylindrosporum showed a significantly lower growth performance. Basically, two related hypotheses have been forwarded to explain lower growth performance of mycorrhizal plants compared to non-mycorrhizal plants. The first hypothesis focuses on carbon costs for the mycorrhizal fungus, while the second hypothesis focuses on nutrient immobilization by the mycorrhizal fungus.

Under the first hypothesis increased carbon availability (through higher rates of photosynthesis) would decrease relative carbon costs to maintain the mycorrhizal fungus. One corollary following from that hypothesis would be that increased $\mathrm{CO}_{2}$ availability reduces carbon costs and hence decreases growth reduction. In our experiment, the growth performance of mycorrhizal plants was independent of $\mathrm{CO}_{2}$ levels. Dry weight of mycorrhizal plants (averaged over seven species) was $91 \%$ of that of non-mycorrhizal plants at ambient $\mathrm{CO}_{2}$ levels and $90 \%$ at elevated $\mathrm{CO}_{2}$ levels. So, increased sink strength for carbon in mycorrhizal plants does not seem to be the cause of the growth reduction. In addition, dry weight of mycorrhizal plants was largely determined by intrinsic fungal properties, notably the length of the extraradical mycelium, because we found significantly negative correlations values. Letters refer to plant shoot (white bars) and root biomass (shaded bars) and between parenthesis for hyphal length

between extraradical hyphal length and shoot weight (Fig. 3a), shoot $\mathrm{N}$ content (Fig. 3b), and total $\mathrm{N}$ uptake (Fig. 3c), indicating the importance of fungal sink strength for $\mathrm{N}$.

Several lines of evidence suggest that this growth reduction of mycorrhizal plants was due to $\mathrm{N}$ immobilization in the extraradical mycelium. An $\mathrm{N}$ balance showed that under ambient $\mathrm{CO}_{2} 76 \%$ of the mineral $\mathrm{N}$ that was in or added to the system could be accounted for in shoots and roots of non-mycorrhizal plants, and that mycorrhizal colonization reduced that to on average $67 \%$. Under elevated $\mathrm{CO}_{2}, 89 \%$ of $\mathrm{N}$ in the system could be accounted for in shoots and roots of non-mycorrhizal plants, and in ECM plants this was on average $68 \%$. Plants colonized by $H$. cylindrosporum, where a very high length of extraradical mycelium was recorded, remained the smallest, despite the high below-ground investment. Because of the $\mathrm{C}$ compounds associated with the immobilization of $\mathrm{N}$, the extraradical mycelium of Hebeloma species has been noted to be a large modifier of plant photosynthesis and carbohydrate metabolism (Miller et al. 1989; Rygiewicz and Andersen 1994; Marmeisse et al. 1999). Also in conditions of low P supply, H. cylindrosporum associated with seedlings of Pinus pinaster reduced plant growth due to $\mathrm{P}$ retention (Conjeaud et al. 1996). When different kinds of $\mathrm{N}$ 


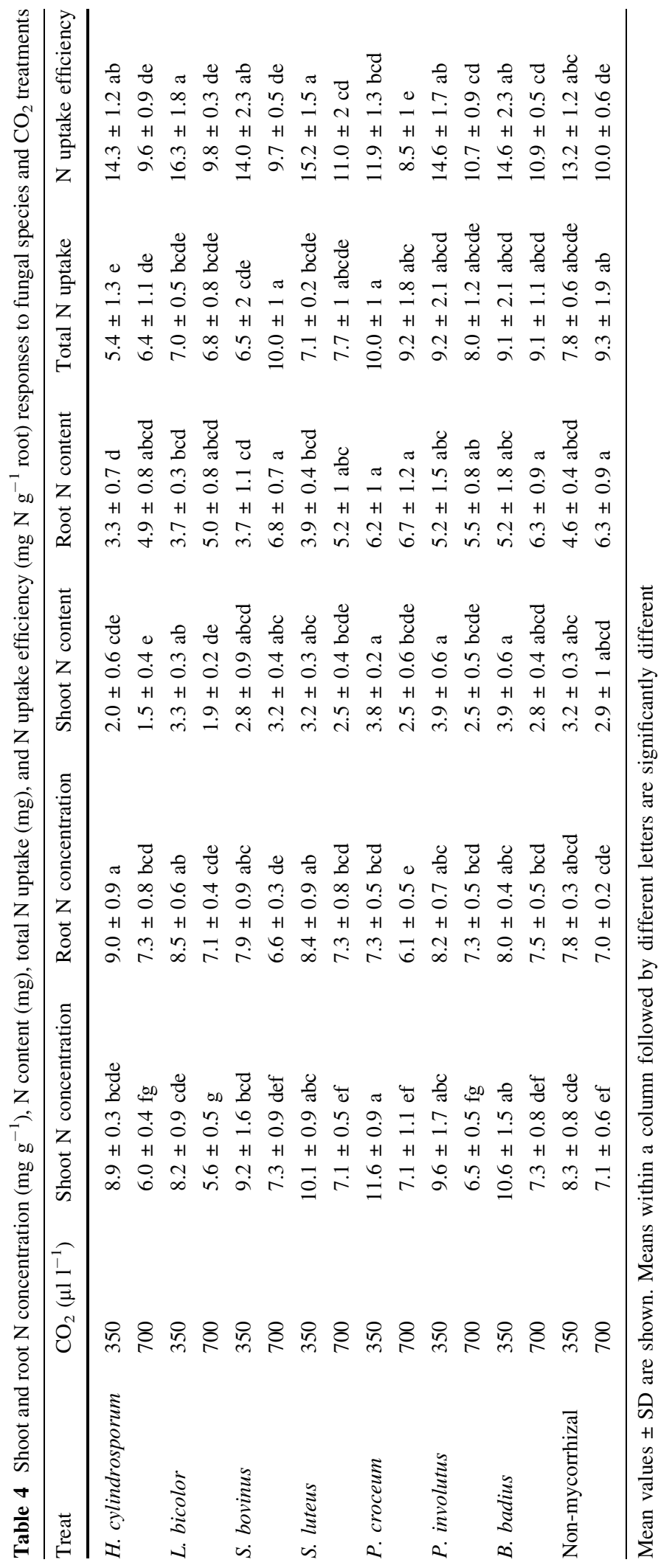




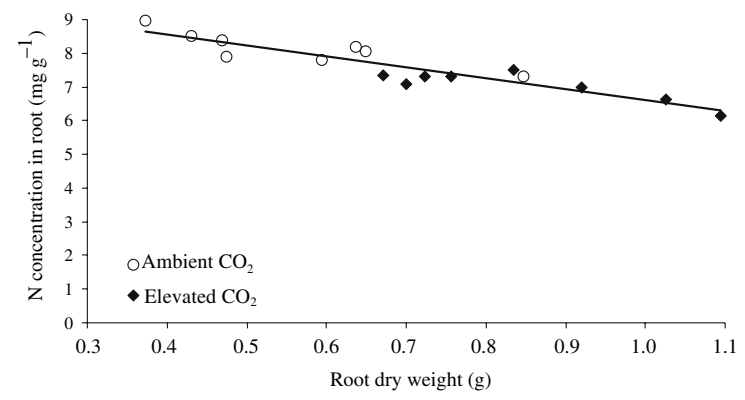

Fig. 2 Relation between root dry weight (g) and root $\mathrm{N}$ concentration $\left(\mathrm{mg} \mathrm{g}^{-1}\right)$ under ambient (open circle) and elevated (filled diamond) $\mathrm{CO}_{2}[n=16, r=-0.908$, and $P<0.001]$
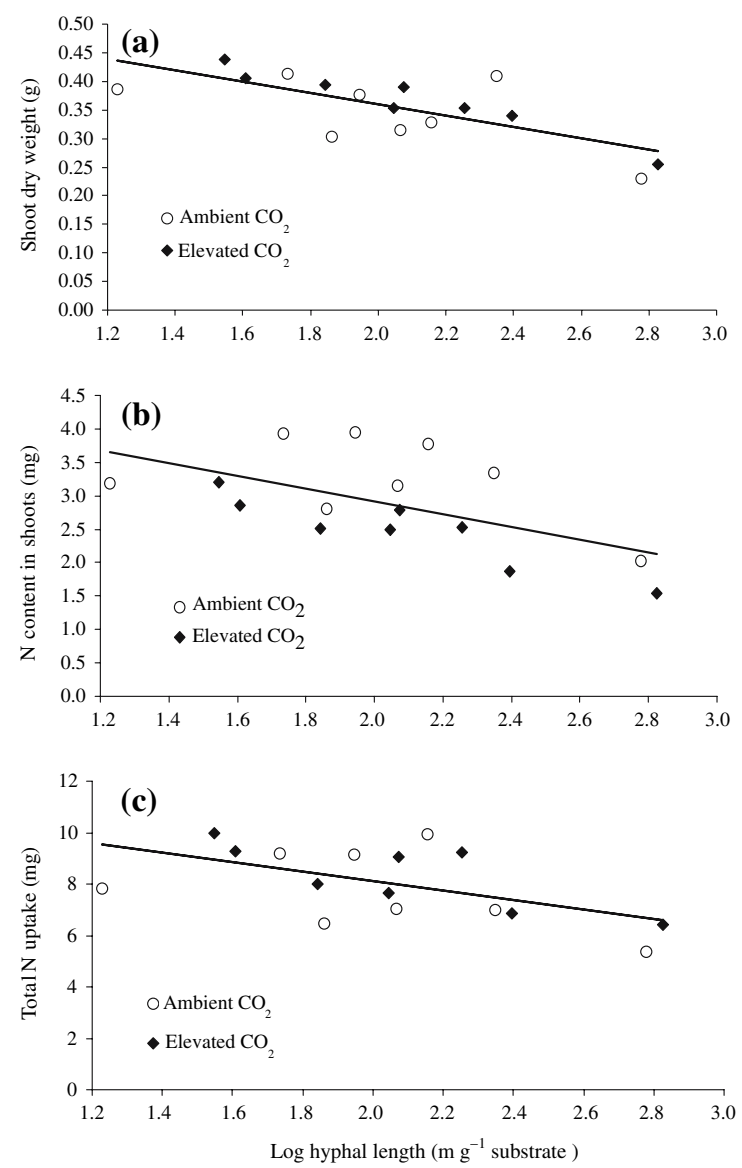

Fig. 3 Relation between hyphal length ( $\log \mathrm{m} \mathrm{g}^{-1}$ substrate) and a shoot dry weight ( $\mathrm{g}$ ), b N content in shoots (mg), and c total $\mathrm{N}$ uptake $(\mathrm{mg})$ under ambient (open circle) and elevated (filled diamond) $\mathrm{CO}_{2}[n=16, r=-0.7$, and $P<0.01$ (a); $r=-0.572$ and $P<0.02$ (b); $r=-0.54$ and $P<0.05$ (c) ]

were supplied to the symbiosis $P$. pinaster $-H$. cylindrosporum, decreased plant growth of the pine was related to the $\mathrm{C}$ cost for fungal growth and $\mathrm{N}$ assimilation, and the extraradical hyphae were considered as the main sink (Plassard et al. 2000). Colpaert et al. (1992) demonstrated a negative correlation between mycelial size and the growth of $P$. sylvestris seedlings and in a subsequent study Colpaert et al. (1996) suggested that growth reduction of pine seedlings colonized by Scleroderma citrinum was best explained by the $\mathrm{N}$-drain.

While in a strict sense our second and third hypothesis were not supported (because under elevated $\mathrm{CO}_{2}$ there were no increases in the size of the extraradical mycelium), the underlying mechanism of mycorrhizal fungal-induced PNL (mycelial size determines fungal $\mathrm{N}$ immobilization potential and hence plant $\mathrm{N}$ concentration and content) was confirmed. While laboratory evidence for nutrient $(\mathrm{N})$ retention by ECM fungi resulting in reduced plant growth was also provided by Nylund and Wallander (1989), Dosskey et al. (1990, 1991), Colpaert and Verstuyft (1999), and Fransson et al. (2005), the question is relevant whether the same mechanism could also occur under field conditions. Instances of very strong N-limitation of ECM mycelial growth has been reported from several boreal and arctic ecosystems (Hendricks et al. 2006; Clemmensen et al. 2006; Wallander 2006). There is also field evidence for $\mathrm{N}$ limitation of arbuscular mycorrhizal fungi (Treseder and Allen 2002; Allen et al. 2005). It is therefore likely that mycorrhizal fungal-induced PNL can also occur under field conditions and will ultimately constrain mycorrhizal plant responses to elevated $\mathrm{CO}_{2}$ (Johnson 2006; Hu et al. 2006).

Further indirect evidence for mycorrhizal-fungal induced PNL comes from $\mathrm{N}$ concentration. In our system shoot and root $\mathrm{N}$ under ambient $\mathrm{CO}_{2}$ ranged between 7 and $12 \mathrm{mg} \mathrm{g}^{-1}$, and under elevated $\mathrm{CO}_{2}$ between 6 and $7 \mathrm{mg} \mathrm{g}^{-1}$. Especially these latter values are clearly below the deficiency limit of $10 \mathrm{mg} \mathrm{g}^{-1}$ as mentioned by Reuter et al. (1997) for pines. Similar low plant N concentrations were also observed in northern Finland in Scots pine and Norway spruce (Picea abies) stands on very poor soils (Helmisaari et al. 2007) with root N concentrations between 5 and $8 \mathrm{mg} \mathrm{g}^{-1}$, indicating that this degree of N-limitation also occurs in natural systems. The high-N retention by mycorrhizal hyphae apparently limits plant growth given the fact that the non-mycorrhizal plants grew somewhat better than the mycorrhizal plants. This confirms our fourth 
Table 5 Shoot and root $\mathrm{P}$ concentration $\left(\mathrm{mg} \mathrm{g}^{-1}\right)$, $\mathrm{P}$ content $(\mathrm{mg})$, and total $\mathrm{P}$ uptake $(\mathrm{mg})$ parameters in responses to fungal species and $\mathrm{CO}_{2}$ treatments

\begin{tabular}{|c|c|c|c|c|c|c|}
\hline Treat & $\mathrm{CO}_{2}\left(\mu \mathrm{l} \mathrm{1^{-1 } )}\right.$ & Shoot $\mathrm{P}$ concentration & Root $\mathrm{P}$ concentration & Shoot $\mathrm{P}$ content & Root $\mathrm{P}$ content & Total P uptake \\
\hline \multirow[t]{2}{*}{ H. cylindrosporum } & 350 & $1.8 \pm 0.4 \mathrm{a}$ & $4.7 \pm 0.5 \mathrm{a}$ & $0.40 \pm 0.08$ & $1.7 \pm 0.3 \mathrm{e}$ & $2.2 \pm 0.3 \mathrm{e}$ \\
\hline & 700 & $2.0 \pm 0.9 \mathrm{a}$ & $3.9 \pm 0.3 \mathrm{abc}$ & $0.50 \pm 0.24$ & $2.6 \pm 0.5 \mathrm{bcde}$ & $3.1 \pm 0.7$ bcde \\
\hline \multirow[t]{2}{*}{ L. bicolor } & 350 & $1.4 \pm 0.1 \mathrm{ab}$ & $4.8 \pm 0.6 \mathrm{a}$ & $0.58 \pm 0.06$ & $2.0 \pm 0.3 \mathrm{de}$ & $2.6 \pm 0.3 \mathrm{de}$ \\
\hline & 700 & $1.2 \pm 0.2 \mathrm{~b}$ & $4.5 \pm 0.3 \mathrm{ab}$ & $0.41 \pm 0.06$ & $3.1 \pm 0.5 \mathrm{abc}$ & $3.5 \pm 0.5 \mathrm{abcd}$ \\
\hline \multirow[t]{2}{*}{ S. bovinus } & 350 & $2.1 \pm 0.9 \mathrm{a}$ & $4.4 \pm 0.3 \mathrm{abc}$ & $0.53 \pm 0.16$ & $2.1 \pm 0.7 \mathrm{cde}$ & $2.6 \pm 0.8 \mathrm{de}$ \\
\hline & 700 & $1.4 \pm 0.2 \mathrm{ab}$ & $3.7 \pm 0.3 \mathrm{abc}$ & $0.60 \pm 0.1$ & $3.8 \pm 0.4 \mathrm{a}$ & $4.4 \pm 0.4 \mathrm{a}$ \\
\hline \multirow[t]{2}{*}{ S. luteus } & 350 & $1.7 \pm 0.4 \mathrm{ab}$ & $4.8 \pm 0.7 \mathrm{a}$ & $0.53 \pm 0.06$ & $2.2 \pm 0.1 \mathrm{cde}$ & $2.7 \pm 0.1 \mathrm{de}$ \\
\hline & 700 & $1.5 \pm 0.2 \mathrm{ab}$ & $4.2 \pm 0.6 \mathrm{abc}$ & $0.51 \pm 0.09$ & $3.0 \pm 0.8 \mathrm{abcd}$ & $3.5 \pm 0.8 \mathrm{abcd}$ \\
\hline \multirow[t]{2}{*}{ P. croceum } & 350 & $1.7 \pm 0.2 \mathrm{ab}$ & $3.5 \pm 0.4 \mathrm{c}$ & $0.54 \pm 0.04$ & $2.9 \pm 0.2 \mathrm{abcd}$ & $3.5 \pm 0.2 \mathrm{abcd}$ \\
\hline & 700 & $1.4 \pm 0.3 \mathrm{ab}$ & $3.6 \pm 0.5 b c$ & $0.50 \pm 0.09$ & $3.9 \pm 0.5 \mathrm{a}$ & $4.4 \pm 0.5 \mathrm{a}$ \\
\hline \multirow[t]{2}{*}{ P. involutus } & 350 & $1.7 \pm 0.2 \mathrm{ab}$ & $4.1 \pm 0.7 \mathrm{abc}$ & $0.72 \pm 0.19$ & $2.5 \pm 0.5 \mathrm{bcde}$ & $3.3 \pm 0.6 \mathrm{abcd}$ \\
\hline & 700 & $1.2 \pm 0.1 \mathrm{~b}$ & $4.1 \pm 0.4 \mathrm{abc}$ & $0.48 \pm 0.11$ & $3.1 \pm 0.5 \mathrm{abcd}$ & $3.6 \pm 0.5 \mathrm{abcd}$ \\
\hline \multirow[t]{2}{*}{ B. badius } & 350 & $1.9 \pm 0.2 \mathrm{ab}$ & $4.5 \pm 0.6 \mathrm{ab}$ & $0.71 \pm 0.08$ & $2.8 \pm 0.8 \mathrm{abcd}$ & $3.5 \pm 0.8 \mathrm{abcd}$ \\
\hline & 700 & $1.3 \pm 0.1 \mathrm{~b}$ & $4.1 \pm 0.6 \mathrm{abc}$ & $0.51 \pm 0.13$ & $3.4 \pm 0.7 \mathrm{ab}$ & $3.9 \pm 0.8 \mathrm{abc}$ \\
\hline \multirow[t]{2}{*}{ Non-mycorrhizal } & 350 & $1.3 \pm 0.1 b$ & $3.9 \pm 0.3 \mathrm{abc}$ & $0.49 \pm 0.07$ & $2.3 \pm 0.3 \mathrm{cde}$ & $2.8 \pm 0.3 \mathrm{cde}$ \\
\hline & 700 & $1.3 \pm 0.2 \mathrm{~b}$ & $3.9 \pm 0.3 \mathrm{abc}$ & $0.53 \pm 0.15$ & $3.6 \pm 0.5 \mathrm{ab}$ & $4.1 \pm 0.6 \mathrm{ab}$ \\
\hline
\end{tabular}

Mean values \pm SD are shown. Means within a column followed by different letters are significantly different

hypothesis. The N: P ratio (ranging between four and seven under both ambient and elevated $\mathrm{CO}_{2}$ ) and $\mathrm{P}$ concentration of shoots (between 1.2 and $2.1 \mathrm{mg} \mathrm{g}^{-1}$ under both ambient and elevated $\mathrm{CO}_{2}$ ), above the deficiency level of $1.0 \mathrm{mg} \mathrm{g}^{-1}$ (Reuter et al. 1997) indicated adequate $\mathrm{P}$ supply.

Alberton et al. (2005) pointed out that a large source of variation between experiments was due to differences between fungal species and stated that argued choices for fungal species selection are very important. ECM fungi show large intrinsic differences in their $\mathrm{N}$ sink strength. Relations between nitrogen availability and fungal carbon use, where increasing $\mathrm{N}$ levels result in a shift from fungal growth toward $\mathrm{N}$ assimilation, have been noted by Arnebrant (1994) and Wallander (1995). ECM fungi can be classified along a gradient from nitrophobic to nitrotolerant or nitrophilic. Gorissen and Kuyper (2000) showed that the nitrophobic S. bovinus could respond to elevated $\mathrm{CO}_{2}$, whereas the nitrotolerant $L$. bicolor did not. In their study, there were no significant differences in hyphal length between both species (although $S$. bovinus tended to form more mycelium), but pine seedlings colonized by $S$. bovinus had significantly higher $\mathrm{N}$ concentrations in shoots and roots, being above deficiency levels in the former case, and below deficiency levels in the latter. One important point if one wants to compare the results of this study with that by Gorissen and Kuyper (2000) is the duration of the experiment; in the present experiment it lasted 2 months longer, thereby increasing N-limitation due fungal and plant growth. Calculations, based on the data in Gorissen and Kuyper (2000) showed that S. bovinus transferred significantly more $\mathrm{N}$ per g ECM than L. bicolor; $\mathrm{N}$-uptake efficiency for the former species was 20 and was reduced to 11 under elevated $\mathrm{CO}_{2}$, for the latter species 12 and slightly reduced to 11 under elevated $\mathrm{CO}_{2}$. Comparison with the present study (N-uptake efficiency of 12-16 under ambient $\mathrm{CO}_{2}$, and 8-11 under elevated $\mathrm{CO}_{2}$ ) suggests additionally that the previous experiment was done under less $\mathrm{N}$-constrained conditions. The decrease in nitrogen uptake efficiency under elevated $\mathrm{CO}_{2}$ shows that additional carbon hardly increase $\mathrm{N}$ uptake, consistent with the PNL hypothesis.

In the present study, differences between fungal species could very well be explained through one factor only, size of the extraradical mycelium. Differences in $\mathrm{C}$ to $\mathrm{N}$ exchange ratios in the fungus were clearly of limited importance. When plant growth is limited by nutrients, plants undergo 
morphological, and physiological modifications. By changing the functional equilibrium between shoots and roots, plants allocate more $\mathrm{C}$ to below-ground structures for nutrient acquisition. If plants allocate more biomass to the organs that are involved in the acquisition of the resource that is currently most limiting, one would predict that elevated $\mathrm{CO}_{2}$ would decrease shoot: root ratio. Our data are consistent with that prediction. Shoot: root ratios declined under elevated $\mathrm{CO}_{2}$ from 0.67 to 0.45 . A meta-analysis, conducted by Poorter and Nagel (2000) showed that under conditions of severe nutrient limitation, elevated $\mathrm{CO}_{2}$ led to a decrease in shoot: root ratio. Our experiments showed the largest reduction in shoot: root ratio in plants that were colonized by those ECM fungal species that had the largest extraradical mycelium, lowest $\mathrm{N}$ concentration in needles under elevated $\mathrm{CO}_{2}$ and lowest ${ }^{14} \mathrm{C}$ incorporation in needles, viz. L. bicolor and H. cylindrosporum. The ultimate effect of this changed allocation of carbon (and unavoidably of nitrogen!) would be that photosynthesis rates go down, in the end to levels where no effect of elevated $\mathrm{CO}_{2}$ on shoot biomass or shoot ${ }^{14} \mathrm{C}$ incorporation was noted (Table 1). The observation that fungal sink strength for $\mathrm{N}$ constrains plant response to elevated $\mathrm{CO}_{2}$ supports our claim that the size of the extraradical mycelium generates potential for negative feedback through PNL (Hu et al. 2006).

The fact that mycelial length, and hence, mycelial biomass did not increase significantly under elevated $\mathrm{CO}_{2}$ (Table 1) could suggest that plants do have some control over allocation of $\mathrm{C}$ to their fungal symbionts. However, increases in the ECM root biomass likely entails increases in fungal biomass on the roots as well. From data by Hobbie and Colpaert (2003) we calculated that fungi contributed $20 \%$ to the ECM root mass of pine seedlings ( $18 \%$ under high N, $21 \%$ under low $\mathrm{N}$-average for $S$. luteus and T. terrestris). Assuming that fungi also contribute $20 \%$ to the mass of the ECM in our study, and converting hyphal length into fungal biomass (treating mycelium as an elongated cylinder with a diameter of $2.7 \mu \mathrm{m}$ and a hyphal density of $1.3 \mathrm{~g} \mathrm{~cm}^{-3}$ (Bloem and Vos 2004), we calculate that the increased allocation belowground under elevated $\mathrm{CO}_{2}$ could increase ECM fungal biomass with on average of $32 \%$ for most species (64\% for $S$. bovinus), remarkably close to the $34 \%$ of generalized fungal response in Alberton et al. (2005).
Shoot dry weight increased with only $6 \%$ under elevated $\mathrm{CO}_{2}$, and this was slightly less than the increase in hyphal length (12\%). However, both changes were not significant. The increase in shoot weight was also less than reported in Alberton et al. (2005). The low above-ground plant response is mainly due to the low $\mathrm{N}$ availability. The experimental system (Petri dish) may not easily allow extrapolation of results into the field. However, this system, which achieves good control over humidity, light availability, temperature, and $\mathrm{CO}_{2}$ level, has been successfully applied in several previous investigations (Ineichen and Wiemken 1992; Ineichen et al. 1995; Fransson et al. 2007).

In conclusion, fungal sink strength for $\mathrm{N}$, together with low $\mathrm{N}$ availability in a restricted growth medium constrained plant growth especially with fungal species with the largest mycelial size. In an experiment where nutrients were not limiting, elevated $\mathrm{CO}_{2}$ resulted both in a rapid positive response by ECM fungi and in an increase in photosynthetic performance by pine seedlings (Fransson et al. 2007). In nutrient-constrained systems, elevated $\mathrm{CO}_{2}$ will increase allocation belowground (to mycorrhizal fungi and roots) and enhance nutrient immobilization by mycorrhizal fungi. However, increased immobilization lowers plant $\mathrm{N}$ concentration and hence restricts the plant's ability to respond to this elevated $\mathrm{CO}_{2}$. Mycelial sink strength then generates negative feedback to plant growth under elevated $\mathrm{CO}_{2}$, as predicted by the PNL hypothesis. If ecosystems are generally 'saturated' (O'Neill 1994) with respect to ECM fungi, calculating the optimal mycelium size, using modeling approaches, taking into consideration soil properties and hyphal distribution in soil is an important challenge.

Acknowledgments This study was funded by the C. T. de Wit Graduate School for Production Ecology and Resource Conservation (PE\&RC) of Wageningen University and Research Centre, The Netherlands. Constructive comments by two anonymous reviewers on an earlier version of the manuscript are gratefully acknowledged.

\section{References}

Alberton O, Kuyper TW, Gorissen A (2005) Taking mycocentrism seriously: mycorrhizal fungal and plant responses to elevated $\mathrm{CO}_{2}$. New Phytol 167:859-868 
Allen MF, Klironomos JN, Treseder KK, Oechel WC (2005) Responses of soil biota to elevated $\mathrm{CO}_{2}$ in a chaparral ecosystem. Ecol Appl 15:1701-1711

Andersen CP, Rygiewicz PT (1995) Allocation of carbon in mycorrhizal Pinus ponderosa seedlings exposed to ozone. New Phytol 131:471-480

Arnebrant K (1994) Nitrogen amendments reduce the growth of extramatrical ectomycorrhizal mycelium. Mycorrhiza $5: 7-15$

Bloem J, Vos A (2004) Fluorescent staining of microbes for total direct counts. In: Kowalchuk GA, de Bruijn FJ, Head IM, Akkermans AD, van Elsas JD (eds) Molecular microbial ecology manual, 2nd edn, vol 402. Kluwer, Dordrecht, pp 861-874

Clemmensen KE, Michelsen A, Jonasson S, Shaver GR (2006) Increased ectomycorrhizal fungal abundance after long-term fertilization and warming of two artic tundra ecosystems. New Phytol 171:391-404

Colpaert JV, van Assche JA, Luijtens K (1992) The growth of the extramatrical mycelium of ectomycorrhizal fungi and the growth response of Pinus sylvestris L. New Phytol 120:127-135

Colpaert JV, van Laere A, van Assche JA (1996) Carbon and nitrogen allocation in ectomycorrhizal and non-mycorrhizal Pinus sylvestris L. seedlings. Tree Physiol 16:787793

Colpaert JV, Verstuyft I (1999) The ingestad concept in ectomycorrhizal research: possibilities and limitations. Physiol Plant 105:233-238

Conjeaud C, Scheromm P, Mousain D (1996) Effects of phosphorus and ectomycorrhiza on maritime pine (Pinus pinaster). New Phytol 133:345-351

Dalal RC (1979) Simple procedure for the determination of total carbon and its radioactivity in soils and plant materials. Analyst 104:151-154

Díaz S, Grime JP, Harris J, McPherson E (1993) Evidence of a feedback mechanism limiting plant response to elevated carbon dioxide. Nature 364:616-617

Dosskey MG, Boersma L, Linderman RG (1991) Role for the photosynthate demand of ectomycorrhizas in the response of Douglas fir seedlings to drying soil. New Phytol 117:327-334

Dosskey MG, Linderman RG, Boersma L (1990) Carbon-sink stimulation of photosynthesis in Douglas fir seedlings by some ectomycorrhizas. New Phytol 115:269-274

Fitter AH, Heinemeyer A, Staddon PL (2000) The impact of elevated $\mathrm{CO}_{2}$ and global climate change on arbuscular mycorrhizas: a mycocentric approach. New Phytol 147:179-187

Fransson PMA, Anderson IC, Alexander IJ (2007) Does carbon partitioning in ectomycorrhizal pine seedlings under elevated $\mathrm{CO}_{2}$ vary with fungal species? Plant Soil 291:323-333

Fransson PMA, Taylor AFS, Finlay RD (2001) Elevated atmospheric $\mathrm{CO}_{2}$ alters root symbiont community structure in forest trees. New Phytol 152:431-442

Fransson PMA, Taylor AFS, Finlay RD (2005) Mycelial production, spread and root colonisation by the ectomycorrhizal fungi Hebeloma crustuliniforme and Paxillus involutus under elevated atmospheric $\mathrm{CO}_{2}$. Mycorrhiza $15: 25-31$
Gorissen A, Joosten NN, Jansen AE (1991) Effects of ozone and ammonium sulphate on carbon partitioning to mycorrhizal roots of juvenile Douglas fir. New Phytol 119:243-250

Gorissen A, Kuikman PJ, van Ginkel JH, van de Beek H, Jansen AG (1996) ESPAS—an advanced phytotron for measuring carbon dynamics in a whole plant-soil system. Plant Soil 179:81-87

Gorissen A, Kuyper TW (2000) Fungal species-specific responses of ectomycorrhizal Scots pine (Pinus sylvestris) to elevated $\left[\mathrm{CO}_{2}\right]$. New Phytol 146:163-168

Helmisaari HS, Derome J, Nöjd P, Kukkola M (2007) Fine root biomass in relation to site and stand characteristics in Norway spruce and Scots pine stands. Tree Physiol (in press)

Hendricks JJ, Mitchell RJ, Kuehn KA, Pecot SD, Sims SE (2006) Measuring external mycelia production of ectomycorrhizal fungi in the field: the soil matrix matters. New Phytol 171:179-186

Hobbie EA, Colpaert JV (2003) Nitrogen availability and colonization by mycorrhizal fungi correlate with nitrogen isotope patterns in plants. New Phytol 157: $115-126$

Hu S, Tu C, Chen X, Gruver JB (2006) Progressive N limitation of plant response to elevated $\mathrm{CO}_{2}$ : a microbiological perspective. Plant Soil 289:47-58

Ineichen K, Wiemken V (1992) Changes in the fungus-specific, soluble-carbohydrate pool during rapid and synchronous ectomycorrhiza formation of Picea abies with Pisolithus tinctorius. Mycorrhiza 2:1-7

Ineichen K, Wiemken V, Wiemken A (1995) Shoots, roots and ectomycorrhiza formation of pine seedlings at elevated atmospheric carbon dioxide. Plant Cell Environ 18:703707

Johnson DW (2006) Progressive N limitation in forests: review and implications for long-term responses to elevated $\mathrm{CO}_{2}$. Ecology 87:64-75

Kamminga-van Wijk C, Prins HBA (1989) The influence of pH on ectomycorrhizal development of Pseudotsuga menziesii inoculated with Laccaria bicolor in hydroculture. Agric Ecosyst Environ 28:213-217

Luo Y, Su B, Currie WS, Dukes JS, Finzi A, Hartwig U, Hungate B, McMurtrie RS, Oren R, Parton WJ, Pataki DE, Shaw R, Zak DR, Field CB (2004) Progressive nitrogen limitation of ecosystem responses to rising atmospheric carbon dioxide. BioScience 54:731-739

Marmeisse R, Gryta H, Jargeat P, Fraissinet-Tachet L, Gay G, Debaud JC (1999) Hebeloma. In: Cairney JWG, Chambers SM (eds) Ectomycorrhizal fungi: key genera in profile. Springer, Berlin, pp 89-127

Miller SL, Durall DM, Rygiewicz PT (1989) Temporal allocation of ${ }^{14} \mathrm{C}$ to extramatrical hyphae of ectomycorrhizal ponderosa pine seedlings. Tree Physiol 5:239-249

Nylund JE, Wallander H (1989) Effects of ectomycorrhiza on host growth and carbon balance in a semi-hydroponic cultivation system. New Phytol 112:389-398

O'Neill EG (1994) Responses of soil biota to elevated atmospheric carbon dioxide. Plant Soil 165:55-65

Parrent JL, Morris WF, Vilgalys R (2006) $\mathrm{CO}_{2}$-enrichment and nutrient availability alter ectomycorrhizal fungal communities. Ecology 87:2278-2287 
Plassard C, Bonafos B, Touraine B (2000) Differential effects of mineral and organic $\mathrm{N}$ sources, and of ectomycorrhizal infection by Hebeloma cylindrosporum, on growth and $\mathrm{N}$ utilization in Pinus pinaster. Plant Cell Environ 23:11951205

Poorter H, Nagel O (2000) The role of biomass allocation in the growth response of plants to different levels of light, $\mathrm{CO}_{2}$, nutrients and water: a quantitative review. Aust $\mathrm{J}$ Plant Physiol 27:595-607

Reich PB, Hungate BA, Luo Y (2006) Carbon-nitrogen interactions in terrestrial ecosystems in response to rising atmospheric carbon dioxide. Annu Rev Ecol Evol Syst 37:611-636

Reuter DJ, Robinson JB, Dutkiewicz C (1997) Plant analysis: an interpretation manual. CSIRO, Collingwood, Australia

Rygiewicz PT, Andersen CP (1994) Mycorrhizae alter quality and quantity of carbon allocated below ground. Nature 396:58-60
Staddon PL (2005) Mycorrhizal fungi and environmental change: the need for a mycocentric approach. New Phytol 167:635-637

Temminghoff EJM, Houba VJG (eds) (2004) Digestion in tubes with $\mathrm{H}_{2} \mathrm{SO}_{4}$ - salicylic acid $-\mathrm{H}_{2} \mathrm{O}_{2}$ and selenium. In: Plant analysis procedures. 2nd ed. Kluwer Academic Publishers, Dordrecht, pp 7-9

Treseder KK, Allen MF (2002) Direct nitrogen and phosphorus limitation of arbuscular mycorrhizal fungi: a model and field test. New Phytol 155:507-515

Wallander H (1995) A new hypothesis to explain allocation of dry matter between mycorrhizal fungi and pine seedlings in relation to nutrient supply. Plant Soil 168-169:243-248

Wallander H (2006) External mycorrhizal mycelia-the importance of quantification in natural ecosystems. New Phytol 171:240-242 